\section{Accounting, performance and accountability challenges in hybrid organisations: a value creation perspective}

Accounting in hybrid organisations

\author{
Giuseppe Grossi
}

Department of Business, Hogskolan Kristianstad, Kristianstad, Sweden; Department of Economic Analysis and Accounting, Nord Universitetet, Bodo, Norway and

Kozminski University, Warszawa, Poland

Jarmo Vakkuri

Faculty of Management and Business, Tampere University, Tampere, Finland, and

Massimo Sargiacomo

Department of Business Administration, Gabriele d'Annunzio University of Chieti and Pescara, Chieti, Italy

\begin{abstract}
Purpose - Drawing upon theoretical insights on value creation perspectives, the authors aim to advance the understanding of performance and accountability in different hybrid organisations.

Design/methodology/approach - The authors conceptualise common theoretical origins of hybrid organisations and how they create and enact value, by reflecting on the Accounting, Auditing and Accountability Journal (AAAJ) special issue articles. Furthermore, the authors propose an agenda for future research into accounting, performance and accountability for hybrid organisations.

Findings - Hybrid organisations can be conceptualised through their approaches to value creation (mixing, compromising and legitimising). This article provides a more detailed understanding of accounting, performance and accountability changes in hybrid organisations.

Practical implications - This contribution also has relevant practical implications for actors, such as politicians, managers, professionals, auditors, controllers and accountants, encased in various hybrid organisations, policy contexts and multi-faceted interfaces between public, private and civil society.

Originality/value - Hybridity lenses reveal novel connections between different types of hybrid organisations and how they create and enact multiple values.
\end{abstract}

Keywords Hybridity, Hybrid organisations, Performance, Accountability, Multiple values

Paper type Research paper

\section{Introduction}

Governing global problems, such as combating climate change, surviving pandemics, alleviating social exclusion or developing sustainable cities, has become a collaborative

(C) Giuseppe Grossi, Jarmo Vakkuri and Massimo Sargiacomo. Published by Emerald Publishing Limited. This article is published under the Creative Commons Attribution (CC BY 4.0) licence. Anyone may reproduce, distribute, translate and create derivative works of this article (for both commercial and non-commercial purposes), subject to full attribution to the original publication and authors. The full terms of this licence may be seen at http://creativecommons.org/licences/by/4.0/legalcode

The authors are grateful for comments and critiques from anonymous $A A A J$ reviewers and $A A A J$ editor, Prof. James Guthrie and Prof. Lee Parker. The views and conclusions expressed within remain the responsibility of the authors.

This study has been supported by the Academy of Finland for the research project on "Performance measurement for hybrid governance" (HYPER) (grant number 326525).
Received 19 October 2021 Revised 25 October 2021 Accepted 26 October 2021 
AAAJ

35,3

exercise between public policies and agencies, private business, economic institutions and civic activities (Vakkuri et al., 2021). While societies, as well as researchers in these societies, increasingly, acknowledge that the interplay between public, private and civil sector domains plays a role in how important forms of financial, public and social value are created, they still face fundamental dilemmas in understanding why, through what mechanisms, and with what impacts this takes place. We pose two questions concerning the interplay between these domains: Why and how do the distinct forms of ownership and institutional logics sometimes

contradict each other and collide? Why and how, at other times, via collaboration of public, private and civil society organisations, do they [i.e. the distinct forms of ownership and institutional logics] promote societal purposes?

In this Accounting, Auditing and Accountability Journal (AAAJ) special issue, this interplay is conceptualised as hybridity. We aim to improve the theoretical and practical understanding of accounting, performance and accountability challenges in hybrid organisations. They are seeking to simultaneously advance public policy goals and business aims through the use of both public and private resources (Battilana and Lee, 2014). This AAAJ special issue focuses on case studies in which the potentials, problems and complications of hybridity and hybrid forms of organising will be explored. By hybridity, we refer to the interplay among public, private and civil society via distinct modes of ownership, parallel but often competing and even conflictual institutional logics, diverse funding bases and various forms of social and institutional control (Kreps and Monin, 2011; Skelcher and Smith, 2015; Grossi et al., 2017). We discuss those inter-organisational relationships, roles, calculative practices and performance measurement systems that operate in the interface between public, private and civil society sectors and therefore have to balance between potentially conflicting goals, institutional pressures and inter-institutional complexities (Hopwood, 1996; Pache and Santos, 2013; Skelcher and Smith, 2015; Kastberg Weichselberger and Lagström, 2019; Conrath-Hargreaves and Wüstermann, 2019). Hybrid organisations need to combine social and political objectives with the ideals of profit maximisation, in the context of complex social structures and diversified accountability regimes (Guthrie, 1993). Hybrid organisations are arrangements that use resources, governance structures and logic derived from different sectors (public, private for-profit and non-profit third sector) with divergent aims and actors (Battilana and Lee, 2014; Pache and Santos, 2013). Hybrid organisations should be able to accommodate the multiple values of public organisations (societal, human and public values), profit organisations (such as financial, commercial viability, efficiency, performance, innovation and growth) and non-profit organisations (such as community, ethical, moral, political and religious values) (Jeavons, 1992). In our view, hybrid organisations are likely to remain an essential instrument in any government's toolbox for societal- and public-value creation. Government has a unique role as a guarantor of public values, but citizens and businesses, hybrid and non-profit organisations are also crucial as active solvers of public policy problems (Bryson et al., 2014). Public values are determined by broad and inclusive dialogue and deliberation informed by evidence and democratic values (Moore, 1995).

Hybridity also exists in the sense of values, identities, actions, activities and practices, where the agents are real people (Kurunmäki, 2004; Noordegraaf, 2007). Consider the role of different actors (such as politicians, business managers, street-level workers, professionals, controllers, auditors and accountants) enveloped in different hybrid settings, at different levels of government or in multi-faceted interfaces between public and private sector roles and identities (Grossi et al., 2020). According to the prior research, the development of accounting tools is complicated because actors may have divergent values and thus interpret the organisational mission differently, making hybrid organisations complicated venues for understanding, valuing and demonstrating performance (Hyndman and McConville, 2018). It is also problematic for hybrid organisations to meet every stakeholder's needs, for instance 
financial and non-financial disclosure, since they may have different interests and values (Kurunmäki and Miller, 2006). In this respect, value pluralism in society may be facilitated by hybrid forms of governance and organisations (Alexius and Cisneros Örnberg, 2015; Thornton et al., 2012; Vakkuri and Johanson, 2020; Campanale et al., 2021). The multiplicity of values can be an opportunity for performance management development in these hybrid settings. However, Mongelli et al. (2019) also underline that, when many actors with different values can collaborate to define performance measurement, they can provide a broad picture of their performance. Therefore, the existence of multiple actors and values is a source of contrast and may create opportunities for accounting and accountability. In our view, values created by hybrid organisations responsible for public programmes and services should not be purely evaluated based on financial results (profit and loss account) but more widely on how they contribute to public value creation, taking an integrated and holistic view of their societal impact (Moore, 1995; Bozeman, 2019).

Society itself also creates hybridity and hybrid organisations, sometimes unintendedly. In the quest for modernity, rational order and legitimacy, influenced by New Public Management (NPM) doctrines and related neo-liberal ideologies, public sector systems in different parts of the globe have adopted some forms of hybrid governance and organisations. It has become common to provide public services (such as infrastructure, utilities, education, healthcare, art, culture and social services) through hybrid organisations operating at the intersection of the public sector and the market (Hood, 2000; Billis and Rochester, 2020; Almqvist et al., 2013; Haigh et al., 2015). Such developments in commissioning public services, welfare mixes, corporate social responsibility and the global rise in social enterprises signify the fluidity of institutional boundaries, which are as porous in modern societies as they may have been in pre-modern ones (Badian, 1983). Hybridity representation occurs at multiple levels of society and produces impacts that remain undetected by many of our current accounting instruments. Accounting theory is not an ideal fit for understanding activities and networks that transcend the institutional or professional boundaries (Hopwood, 1996; Kurunmaki and Miller, 2006). We observe an essential research gap concerning the role and impacts of hybridity and hybrid organisations on the design, strategies, value creation, measurement and evaluation of current service delivery systems and societal governance at large (Grossi et al., 2017,2020). The AAAJ special issue articles explore the relevant inter-disciplinary area of research to which the accounting community should contribute more and different types of hybrid organisations operating in different policy fields (See Table 1).

With their different theoretical frameworks and methodological designs, the articles explore accounting, accountability and the performance challenges of the relevant and complex forms of hybridity among the institutional contexts. For this, we present a theoretical framework to conceptualise these hybrid settings as enacting three forms of value creation in hybrid organisations: mixing, compromising and legitimising. First, as value has a mixed, and therefore ambiguous, character, mixing becomes a value-creation mechanism as it relates to the process of combining previously created or existing value categories with the aim of creating novel variants, blends and layers of value (Nicholls, 2009). Second, managing competing, contradictory and even conflictual values in hybrid organisations necessitates innovative mechanisms of compromising. Hybrid organisations are incentivised, sometimes, as they are under pressure to reconcile competing value-creation logics by reaching compromises between different value interests, owners, actors and even calculative practices (Campanale et al., 2021). Third, legitimacy is a crucial concern for hybrid organisations as there are legitimacy demands from external stakeholders, society and media that may generate performance measurement tensions. Moreover, legitimising value concerns not only justifying the past activities of hybrid organisations but also recognising that value is created through the processes of legitimisation (Vakkuri and Johanson, 2020; Vakkuri et al., 2021).

Accounting in hybrid organisations 


\section{AAAJ} 35,3

\section{0}

Table 1.

Types of hybrid organisations in the AAAJ special issue articles
Authors and titles of the articles

Baudot et al. (2022), Hybrid organisations and an ethic of accountability: the role of accountability systems in constructing responsible hybridity

Begkos and Antonopoulou (2022), Hybridisation as practice: clinical engagement with performance metrics and accounting technologies in the English NHS

Convery and Kaufman (2022), Regulation as a force for hybrid organisation: evidence from the Bonneville Power Administration (1980-2012)

Ferry and Slack (2022), (Counter) accounting for hybrid organising: a case of the Great Exhibition of the North

Kastberg Weichselberger and Lagström (2022), Accounting in and for hybrids. Observations of the power of disentanglements Maine et al. (2022), Ambidextrous sustainability, organisational structure and performance of hybrid organisations

Maran and Lowe (2022), Competing logics in a hybrid organisation: ICT service provision in the Italian healthcare

Moriniére and Georgescu (2022), Hybridity and the use of performance measurement: facilitating compromises or creating moral struggles? Insights from healthcare organisations

Rajala and Kokko (2022), Biased by design - the case of horizontal accountability in a hybrid organisation

Rautiainen et al. (2022), Accounting, microfoundations, hybridisation and longitudinal conflicts in a Finnish healthcare organisation

Sargiacomo and Walker (2022), Disaster governance and hybrid organisations: accounting, performance challenges and evacuee housing

Schrøder et al. (2022), What is a good work in a hybrid organisation? On the efforts of sequencing registers of valuation

Stafford and Stapleton (2022), The impact of hybridity on PPP governance and related accountability mechanisms: the case of UK education PPPS

Zawawi and Hoque (2022), Network control and balanced scorecard as inscriptions in purchaser-provider arrangements: insights from a hybrid government agency
Types of hybrid organisations

Hybrid-purpose institutional forms

Healthcare organisations

Hybrid public entity for power administration

Hybrid organisation for cultural events

Hybrids in social investments

Hybrid social housing

Information and communication technology (ICT) services

Healthcare organisations

Alliances between public, private and non-profit organisations

Healthcare organisations

Network for humanitarian activities in natural disasters

Hybrids for child protection

Public and private partnerships (PPPs) in schools

Purchaser-provider models

This article is organised as follows. In Section 2, we generate a general framework for conceptualising hybrid organisations through multiple values and how those multiple values may be mixed, compromised and legitimised. In Section 3, we analyse the 14 articles accepted in this AAAJ special issue, using the value-creation lens. Finally, we synthesise our conclusions and propose research agendas for further investigating hybridity and hybrid organisations.

\section{Mixing, compromising and legitimising multiple values in hybrid organisations}

Hybrid contexts of organisations provide some fundamental problems for value-creation efforts. First, determining the values is not easy, due to the inherent characteristics of value pluralism in hybrid settings. It is common to use concepts, such as market, financial, social and public value and the respective combinatory assemblages to denote multiple values in hybrid organisations' activities (Emerson, 2003; Nicholls, 2009; Quélin et al., 2017; Bozeman, 2019). 
Second, we should understand the mechanisms through which hybrid organisations act upon prevailing (yet ambiguous and contested) notions of value. Prior research on value creation has widely concentrated on this problem of "doing" value (instead of "knowing" about value) (Pfeffer and Sutton, 1999; Vakkuri, 2010). In other words, the emphasis has been on "valorisation" in augmenting the conditions for generating value rather than on "evaluation" in statically assigning value to a given sound, service or societal activity (Vatin, 2013).

Moreover, prior research represents forms of "doing" value by defining conditions in which value is produced, enhanced and facilitated (Vakkuri and Johanson, 2020). Consider the notion of "creating" value as a process by which an individual, organisation or society develops novel and innovative tasks and services for different purposes (Lepak et al., 2007), "capturing" value through which actors that have not been involved in the process of value creation retain some of the value created earlier (Coff, 1999; Jacobides et al., 2006) or "exchanging" value as the realisation of the monetary amount through the process of exchange from the viewpoint of the seller or the buyer (Lepak et al., 2007; Mazzucato, 2018). The variety of words for "doing" value exemplifies the manifold nature of value creation. It might be a neutral activity in increasing the worth of current value. However, it may also include destroying the fruits of previous value generation. It may involve the generation of totally new categories of value that need to be explicated (Plé and Cáceres, 2010).

Value creation mechanisms incorporate different constellations of actors, processes and outcomes. There are value creators as subjects. Someone produces, while others are the users of, value. Several producers may be involved in collaborating in value creation ("coproducing" value) (Ramirez, 1999). The research tradition also introduces the dynamics of how values may be generated (Vatin, 2013). For instance, it may be about "balancing" different logics of value creation or "sharing" some of the value with other stakeholders and communities (who may not have been the intended beneficiaries of the value generation efforts in the first place). Finally, prior research has also widely reflected upon the multitude of variants in the outputs of value creation.

Value-creation efforts may be organised differently in both time and space. We may conceptualise value-creation mechanisms as being nested into each other in several ways, where, for instance, one value creation mechanism may constitute the core, while another mechanism would be more peripheral. Following Kiser and Ostrom (1982), value-creation mechanisms would indicate different levels of choices. Individuals make operational choices authorised by collective choices, which construct institutions to make policy decisions authorised by constitutional choices. While collective choices legitimise and create the entities involved in collective and operational choice processes, constitutional choices design the rules for making decisions: decisions about decision-making rules (Ostrom, 2005).

Furthermore, we may adopt a temporal perspective to comprehend how value creation mechanisms could be structured or sequenced in time. Value creation can be viewed as a cyclical development in the space-time continuum and one in which value-creation mechanisms follow one another in ongoing yet unanticipated, sometimes serendipitous, loops. There are obstacles to linear assumptions of time, as there may not be definite starting and finishing points for value-creation efforts in hybrid organisations.

The papers of this AAAJ special issue scrutinise different contexts of hybrid organisations and activities to interpret these inter-linkages. Consider Convery and Kaufman (2022) scrutinising Bonneville Power Administration, a hybrid energy marketing agency that combines constitutive-level choices of regulation with collective and individual choices of strategising, through the interplay of logics of state intervention and market orientation, and how this has evolved over time. Moreover, consider Sargiacomo and Walker's (2022) discussion of the hybridity of a disaster governance case in which public value creation was significantly conditioned but also influenced by the ability of actors from 
AAAJ 35,3

582 different levels and professions to communicate their choices. Over time, the temporal loops of those value-creation activities help us understand the complexity of value-creation efforts among hybrid organisations and systems. It would be inticing to see value creation proceeding from designed combinations of public and private activities, leading to compromises over the suitable division of work between parties only to result in the legitimate configuration of all the ingredients. Both examples provide limitations for such an argumentation: value creation is much more complicated than that.

To conceptualise value-creation efforts in the hybrid types of the AAAJ special issue (see Table 2), we refer to three mechanisms for understanding the impacts of hybridity on both value creation processes and organisations that pursue value generation under the pressures of distinct logics, performativities and accountabilities. The frame used is mixing, compromising and legitimising mechanisms of value creation among hybrids. We also acknowledge the several opportunities regarding how the links between mixing, compromising and legitimising value may be understood to explain the activities and accountabilities of hybrid organisations.

\section{Mixing}

Mixing multiple value categories may take several forms in hybrid organisations. One common feature of these is combining some previous or existing value categories to contribute to novel value variants. For instance, hybrid organisations may blend values by amalgamating new value combinations from original ones, where the new ones are not discernible from the old ones. Furthermore, there may be layered mixes of value in which hybrids turn original value constellations into new constructs in which the previous value layers remain visible. For instance, value creation outputs may adopt "transformative" forms, they may become "blended" constructs of the previous value creation variants or previous value categories may have been modified into new variants of value through "layered" structure of value (Nicholls, 2009; Polzer et al., 2016).

Hybrids combine a variety of institutional arrangements and connect a variety of diversified value-creation processes. Mixing may concern the exploration of novel combinations between shareholders' interests and public interest. For instance, stateowned enterprises are such a case (Giosi and Caiffa, 2020; Okhmatovskiy, 2021). Moreover, mixing may refer to blending mission orientations and for-profit logic that come with financial performance pressures in social enterprises (Costa and Andreus, 2021). As representations of value constellations, performance measurement models should trace innovative mixes of multiple values reflecting the complexities of these hybrid contexts (De Waele et al., 2021). Mixing forms of value may be a deliberate process of combining two or more value categories and value-creation processes into a single value construct. However, it might also be an accidental process that does not require particular human information processing (Teece, 1986). Furthermore, experimental mixing may combine conscious attempts with accidental elements, as in experimenting with any substances without knowing their reactive outcomes. Similarly, mixing forms of value in hybrid settings of institutional activities may take place intentionally or unintentionally. The former refers to mixing forms of value "by design", whereas the latter relates to mixing forms of value "by default" (Johanson and Vakkuri, 2017). Accounting research needs to be cognisant of both perspectives and their respective impacts on researching hybrid organisations.

\section{Compromising}

Compromising forms of value creation in hybrid settings concerns solving explicit or implicit grievances among the interacting parties. This is particularly relevant in hybrid settings, due to the importance of managing contradictory and even conflictual value constellations 


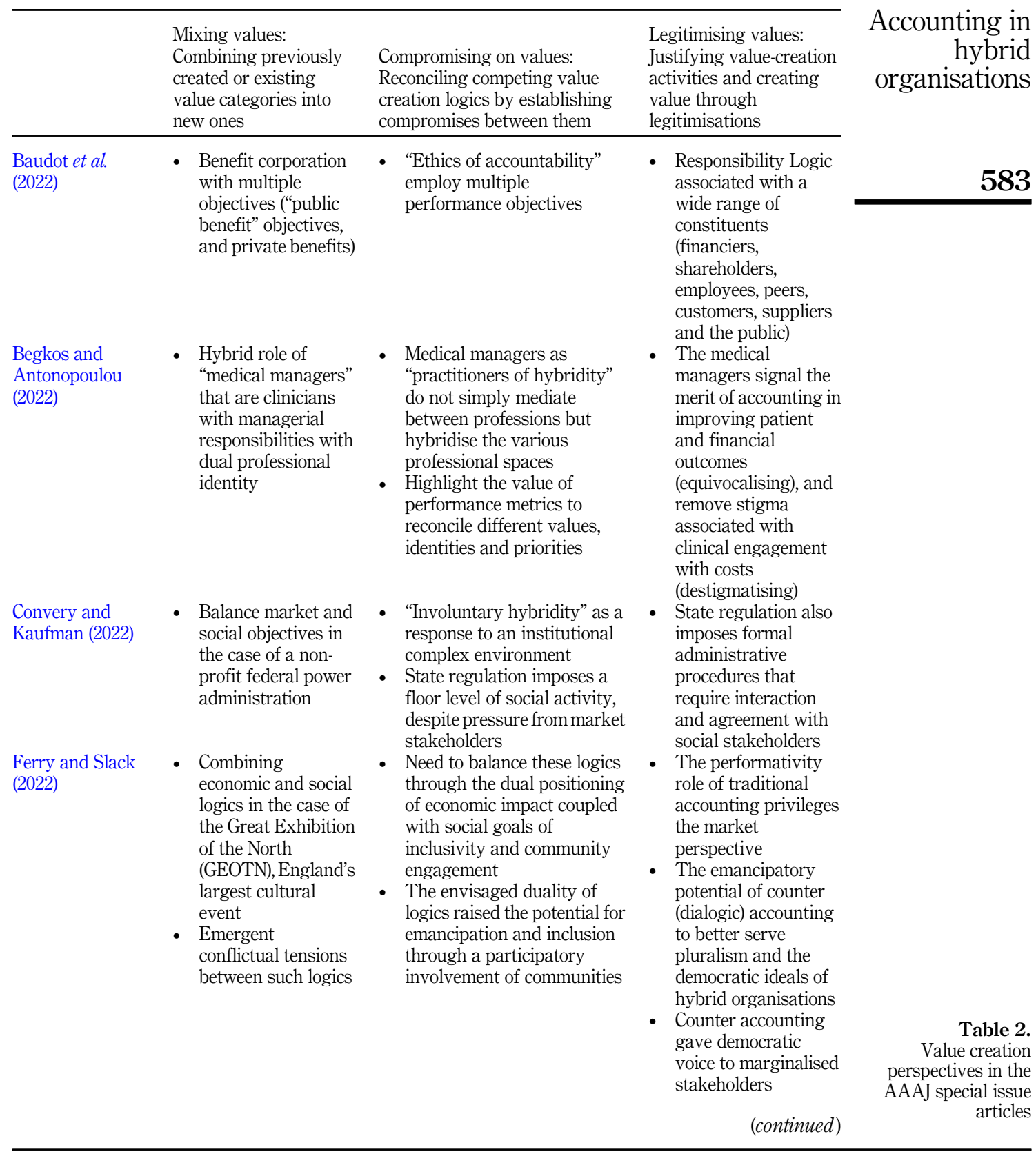




\section{AAAJ 35,3}

584

\begin{tabular}{lll}
\hline Mixing values: & & Legitimising values: \\
Combining previously & Compromising on values: & Justifying value-creation \\
created or existing & Reconciling competing value & activities and creating \\
value categories into & creation logics by establishing & value through \\
new ones & compromises between them & legitimisations \\
\hline
\end{tabular}

Kastberg

Weichselberger

and Lagström

(2022)

Maine et al. (2022) - Social housing has to achieve financial, social and environmental outcomes

Maran and Lowe,
(2022)

- Three different logics (regulatory/ bureaucratic, market and service)

Moriniére and

Georgescu (2022)
- How accounting mediates hybrid settings (while also being mediated) and the role of disentanglements in such processes

- Ambidextrous sustainability strategies encapsulate the simultaneous pursuit of divergent strategic orientations and incorporate the "paradox of strategising" and the "paradox of performing"

- The organisational control mechanisms to balance different logics

- Operationalisation of centrality (to include strategy, performance and control (P\&C) system design, service quality satisfaction) and compatibility of logics (to include accountability considerations, regulatory outcomes and hiring and socialisation practices)

- Performance measures may play an ambivalent role in mitigating these tensions by enabling compromises between actors with divergent values and enhancing tensions between actors with convergent values, such as healthcare professionals
- Social investments entail a design idea that presupposes a new relationship as heterogenous actors enter a relationship of shared resources and goals

- These strategies organisations to respond to expectations of different stakeholders within and outside the organisations in obtaining different facets of performance

- Reshaping of healthcare public sector accountabilities among levels of government (such as regional government and local healthcare providers) as a result of NPM and NPG reforms

- The use of performance measures may bring moral risks and injustice that require social actors to construct different arguments for different audiences enable hybrid
- Healthcare organisations are hybrids as their mission of "care," and the value of "public service" are likely to be in tension with "efficiency"

- The moral struggles related to the conflicting nature of hybridity

Table 2. 


\begin{tabular}{|c|c|c|c|c|}
\hline & $\begin{array}{l}\text { Mixing values: } \\
\text { Combining previously } \\
\text { created or existing } \\
\text { value categories into } \\
\text { new ones }\end{array}$ & $\begin{array}{l}\text { Compromising on values: } \\
\text { Reconciling competing value } \\
\text { creation logics by establishing } \\
\text { compromises between them }\end{array}$ & $\begin{array}{l}\text { Legitimising values: } \\
\text { Justifying value-creation } \\
\text { activities and creating } \\
\text { value through } \\
\text { legitimisations }\end{array}$ & $\begin{array}{r}\text { Accounting in } \\
\text { hybrid } \\
\text { organisations }\end{array}$ \\
\hline $\begin{array}{l}\text { Rajala and Kokko } \\
(2022)\end{array}$ & $\begin{array}{l}\text { - Hybrid } \\
\text { organisations that }\end{array}$ & The mixture of public, & - The different actors & 585 \\
\hline & $\begin{array}{l}\text { have public, private } \\
\text { and third sector } \\
\text { actors providing a } \\
\text { wide range of public } \\
\text { services } \\
\text { Accountability in } \\
\text { public, private and } \\
\text { third sectors }\end{array}$ & $\begin{array}{l}\text { accountability systems are } \\
\text { blended in a hybrid } \\
\text { organisation } \\
\text { Balanced, unbalanced, } \\
\text { dynamic and static } \\
\text { accountability system } \\
\text { models for hybrids }\end{array}$ & $\begin{array}{l}\text { accountable to each } \\
\text { other in horizontal } \\
\text { relationships with the } \\
\text { hybrid organisation }\end{array}$ & \\
\hline $\begin{array}{l}\text { Rautiainen et al. } \\
(2022)\end{array}$ & $\begin{array}{l}\text { - Healthcare } \\
\text { (medical), } \\
\text { administrative and } \\
\text { political } \\
\text { institutional logics } \\
\text { were observed in the } \\
\text { case of a Finnish } \\
\text { healthcare } \\
\text { organisation }\end{array}$ & $\begin{array}{l}\text { Negative emotions stirred by } \\
\text { a pressure to adopt hybrid } \\
\text { practices aggregated into } \\
\text { incompatible institutional } \\
\text { logics led to conflict and } \\
\text { prevented the use of } \\
\text { accounting tools in the } \\
\text { professional }\end{array}$ & $\begin{array}{l}\text { Accounting practices } \\
\text { need to satisfy all } \\
\text { professional groups } \\
\text { to avoid non- } \\
\text { hybridisation } \\
\text { between professional } \\
\text { groups }\end{array}$ & \\
\hline $\begin{array}{l}\text { Sargiacomo and } \\
\text { Walker (2022) }\end{array}$ & $\begin{array}{l}\text { - Network of public } \\
\text { and private } \\
\text { companies with } \\
\text { multiple goals } \\
\text { (public interest and } \\
\text { cost efficiency) } \\
\text { - Short and long-term } \\
\text { humanitarian } \\
\text { activities following } \\
\text { natural disasters }\end{array}$ & $\begin{array}{l}\text { A mix of experts } \\
\text { (accountants, engineers and } \\
\text { architects) developed a } \\
\text { comprehensive reporting } \\
\text { system } \\
\text { - Technologies of government } \\
\text { homogenised administrative } \\
\text { procedures among experts }\end{array}$ & $\begin{array}{l}\text { Financial and non- } \\
\text { financial measures } \\
\text { were taken for } \\
\text { various purposes, } \\
\text { ranging from internal } \\
\text { planning, } \\
\text { coordination and } \\
\text { decision-making to } \\
\text { deviance analysis, as } \\
\text { well as for external } \\
\text { accountability }\end{array}$ & \\
\hline \multirow[t]{2}{*}{$\begin{array}{l}\text { Schrøder et al. } \\
(2022)\end{array}$} & $\begin{array}{l}\text { - Public child } \\
\text { protection agency at } \\
\text { the intersection } \\
\text { between market and } \\
\text { the public sector } \\
\text { - Combine the goals of } \\
\text { cost-efficiency and } \\
\text { of meeting the needs } \\
\text { of the individual } \\
\text { child }\end{array}$ & $\begin{array}{l}\text { - "Sequencing" is ongoing } \\
\text { process of moving } \\
\text { conflicting activities and } \\
\text { bringing them together again } \\
\text { - compartmentalisation" is a } \\
\text { means of avoiding clashes by } \\
\text { combing different and } \\
\text { conflicting way of achieving } \\
\text { goals }\end{array}$ & $\begin{array}{l}\text { Hybridisation is } \\
\text { continuously } \\
\text { evolving and can be } \\
\text { achieved on a day-to- } \\
\text { day basis } \\
\text { - Sequencing is how } \\
\text { accountants, } \\
\text { caseworkers, } \\
\text { consultants and } \\
\text { managers pursue } \\
\text { conflicting ideals of } \\
\text { good performance }\end{array}$ & \\
\hline & & & (continued) & Table 2. \\
\hline
\end{tabular}


AAAJ 35,3

Zawawi and Hoque (2022)

\section{Stafford and}

Mixing values:

Combining previously created or existing value categories into new ones Stapleton (2022)

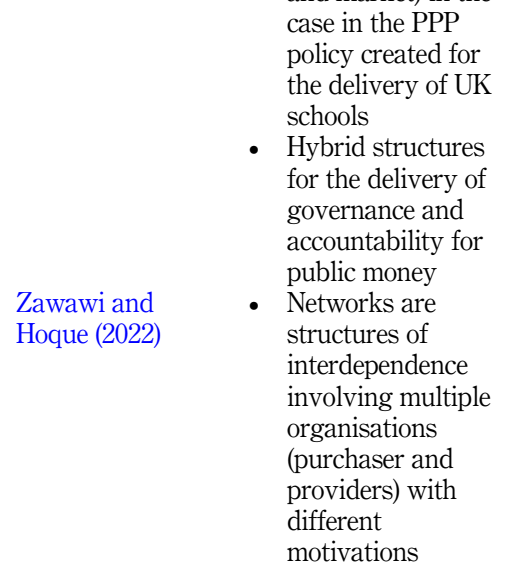

- Multiple logics (community, public case in the PPP policy created for the delivery of UK (chools Hybrid structures for the delivery of governance and accountability for

structures of interdependence involving multiple organisations providers) with motivations
Compromising on values:

Reconciling competing value creation logics by establishing compromises between them
Legitimising values: Justifying value-creation activities and creating value through legitimisations
- "Layering" and "blending" combinations lead to an increasing adoption of private sector accountability

- A parallel "co-existence" of community and market logics delivered a long-term governance structure

- Network control mechanisms involve the integration of different control mechanisms within a network
- The empirical complexity shows that there is no clear "best" combination of engagement between logics and hybrid types of structures for delivering "successful" projects in this environment

- Inscriptions should be scaled down to different subsets and to establish icons without changing their meanings, which is important when external expectations are to be operationalised locally

Table 2.

(Kreps and Monin, 2011; Porter and Kramer, 2011). Not only does compromise require conscious attempts to reach meaningful social outcomes, but there is also an element of reciprocal interaction. A compromise implies that the interests of both (or more) parties are taken into account in the resolution, and none of the parties gets to realise all of its interests. In many hybrid settings, this may contribute to only incomplete, satisficing mixes of value that do not manifest the "best of both worlds" but, rather, "a little bit of everything" (De Waele et al., 2021) or "either hollow politics or lousy business" (Vakkuri et al., 2021).

It is also the case that a compromise may not always be fair, as some participants may need to give up more of their interests and preferences than they would like to, just for the sake of compromise. Such an effort may involve a great deal of "balancing", "sharing" or "blending". It may even include selective coupling (Pache and Santos, 2013). When compromising between multiple and competing values, hybrid organisations do not necessarily appropriate one monolithic logic structure. Instead, they may use multiple logics to serve several parallel purposes and external demands. In a sense, they shop for different sub-structures of value creation logic. For instance, healthcare organisations may select some features of "social welfare logic" to justify their strategies while still keeping their primary focus on financial performance and business interests.

Compromise is an instrument for reconciling competing values and interests in hybrid organisations. While necessary for the institutional survival of hybrids, it may be organised in several ways, for instance through compromising accounts or distinct variants of performance dialogues (Chenhall et al., 2013; Moynihan, 2005). State-owned enterprises are an example of the compromising logic in hybrid organisations and the respective problems and complications that may arise between distinct owners' interests (Mahoney et al., 2009; 
Bruton et al., 2015). Furthermore, forms of compromising can be applied to different types and levels of accountabilities that may exist within intra-organisational or inter-organisational settings (Rajala and Kokko, 2022). Even a performance measurement exercise is a compromise of multiple rationalities enacted in hybrid organisations. Perhaps, the success of performance measurement models should not be evaluated as a deviation from an idealistic notion of absolute rationality or optimality but, rather, as an innovative compromise of values that may create productive friction and thereby contribute, albeit to a minor extent, to the public, financial and social forms of value (Chenhall et al., 2013). This aspect is reflected in this AAAJ hybrid organisations special issue.

\section{Legitimising}

Value creation in hybrids rests on legitimacy in two ways. First, the legitimacy of value creation outputs needs to be demonstrated. This is a significant puzzle for hybrids. How do they measure the multitude of created values? Who is to be credited or blamed for the successes and failures of hybrid activities? Hybrids are inherently attuned to catering to the demands of multiple audiences: the government, citizens and clients, different constituencies and the competitive markets.

Therefore, in terms of legitimisation, the multiplicity of value creation logic is both a curse and a blessing for hybrid organisations (Karré, 2020). Incompatibility of logic may cause tensions, conflicts and locked-in structures, resulting in ambiguous and inconsistent forms of value. However, it also gives leeway to decide how to legitimise value creation efforts for the different audiences. Hybrid organisations may be incentivised to make loose promises, as it is doubtful that any system of accountabilities would demonstrate all the broken promises, let alone attribute credit or blame in evaluating whether the broken promises are due to the success or failure of hybrid activities. Therefore, hybrid organisations may have the option to choose the modes of value they wish to demonstrate and to not disclose those forms of value they wish to hide. This phenomenon is significant for accounting studies and discussed in corporate social responsibility (CSR) research (Matten and Moon, 2008.)

The legitimacy concerns are not only associated with how the value of outputs may be justified. Among hybrids, value can be created through legitimisation. Legitimacy is related to accepting or complying with (1) something that has been considered legitimate in the past (traditional legitimacy), (2) something that works "in practice", based on the justification of relevant audiences (rational-legal legitimacy) and (3) the say-so of somebody in the community that the relevant audiences consider legitimate (charismatic legitimacy) (Suddaby et al., 2017). An aspect of the legitimacy of hybrid activities relates to the existence of multiple audiences. They might embrace community values for a civic audience, public values for a government audience and economic values for a business audience. Accordingly, legitimisation efforts are often manifested in performance measurements, where the institutionalisation of performance (e.g. institutional performance) through socially constructed frames becomes a means to an end (Modell, 2019, 2021). While among non-profit organisations, notions of "justified performance" are interpreted differently among donors, financiers, recipients and other stakeholders, respectively, strategies of constructing institutional performances must vary.

\section{Value creation perspectives in the AAAJ special issue articles}

Next, we move to the introduction and analysis of the papers of our special issue. Our analysis concentrates on the forms and mechanisms of value creation in the cases of hybrid organisations. For that, we use our framework of mixing, compromising and legitimising value among hybrid organisations. Table 2 illustrates the articles as exemplary cases of the 
AAAJ

35,3

588

three value-creation mechanisms and demonstrates the wide variety of value-creation mechanisms in different types of hybrid organisations that the articles introduce. It shows that hybrids combine a variety of goals, activities, institutions and institutional logic, as well as a variety of value-creation mechanisms.

Mixing values can be related to multiple objectives. Some AAAJ special issue articles relate to "public benefit" objectives and private benefits in the case of benefit corporations (Baudot et al., 2022), market and social objectives in a federal power administration (Convery and Kaufman, 2022), financial, social and environmental objectives in social housing companies (Maine et al., 2022), short- and long-term humanitarian activities (Sargiacomo and Walker, 2022), the goals of cost-efficiency and the needs of individual childcare (Schrøder et al., 2022), and the mission of "care" and the value of "public service" with "efficiency" (Moriniére and Georgescu, 2022). Other articles demonstrated the existence of and tensions between the multiplicity of institutional logics, such as economic and social logics (Ferry and Slack, 2022); the logics of calculating the long-term social and economic impacts of preventive social investments (Kastberg Weichselberger and Lagström, 2022); regulatory/bureaucratic, market and service logics in the case of information and communication technology (ICT) service providers (Maran and Lowe, 2022); community, public and market logics in the case of public and private partnership (PPP) policies (Stafford and Stapleton, 2022) and healthcare (medical), administrative and political-institutional logics (Rautiainen et al., 2022). Other studies provided evidence of a variegated mix of different institutions, such as alliances between public, private and third-sector actors (Rajala and Kokko, 2022); a network of public and private companies (Sargiacomo and Walker, 2022) and networks of multiple organisations (purchaser and providers) with different motivations (Zawawi and Hoque, 2022). Begkos and Antonopoulou's (2022) study focuses on the hybrid role of "medical managers", who are clinicians with managerial responsibilities, thus carrying dual professional and hybrid identities.

Compromising on values is an instrument for reconciling competing value-creation logics and interests may be organised in several ways. Some studies related to hybridity on health and social care organisations recognise the role of performance measurement as a mediating and compromising one (Begkos and Antonopoulou, 2022; Maran and Lowe, 2022; Zawawi and Hoque, 2022; Kastberg Weichselberger and Lagström, 2022; Sargiacomo and Walker, 2022). Other studies show that performance measures may play an ambivalent role in mitigating the tensions, by enabling compromises between actors with divergent values, and enhancing tensions between actors with convergent values (Moriniére and Georgescu, 2022). Also, negative emotions stirred by a pressure to adopt hybrid practices aggregated into incompatible institutional logic may lead to conflict and prevent the use of accounting tools in professional hybridisation (Rautiainen et al., 2022). Other studies focus on the role of accountability mechanisms in constructing what is called "responsible hybridity" (Baudot et al., 2022) or "blended accountability" (Rajala and Kokko, 2022). Other scholars believe that compromise between conflicting values and logic can be achieved in several ways. Convery and Kaufman (2022) propose the concept of "involuntary hybridity" as a response to complex institutional pressures. Ferry and Slack (2022) show the emergent conflictual tensions between social and economic logic and the need to balance these logics through. Maine et al. (2022) propose that ambidextrous sustainability strategies encapsulate the simultaneous pursuit of divergent strategic orientations.

Legitimising values in the articles show many actors' efforts to legitimise value creation in hybrid organisations. The most relevant aspect of legitimisation is communicating simultaneously with different stakeholders and audiences. The paper on social investments emphasises a design idea that presupposes the formation of new associations and relationships (Kastberg Weichselberger and Lagström, 2022). The paper on social housing emphasises the strategies that enable hybrid organisations to respond to the 
expectations of different stakeholders (Maine et al., 2022). The study on the Great Exhibition emphasises the emancipatory potential of counter (dialogic) accounting to serve pluralism better and give a democratic voice to marginalised stakeholders (Ferry and Slack, 2022). The study on power administration illustrates how state regulation also imposes formal administrative procedures that require interaction and agreement with social stakeholders (Convery and Kaufman, 2022). Furthermore, legitimisation strategies are connected to different types of accountabilities. The study on benefit corporations emphasises the "ethics of accountability" and responsibility logic associated with a wide range of constituents (Baudot et al., 2022). The study on ICT service provision suggests reshaping healthcare sector accountabilities among levels of government as a result of NPM and New Public Governance (NPG) reforms (Maran and Lowe, 2022). In their work on Finnish alliances, Rajala and Kokko (2022) show that the different actors should be accountable in horizontal relationships with the hybrid organisation. Furthermore, legitimisation strategies are often created in different forms of performance measurements (De Waele et al., 2021). The study on the English National Health Service (NHS) demonstrates how the medical managers signal the merit of performance measures in improving patient and financial outcomes and remove stigma associated to clinical engagement with costs (Begkos and Antonopoulou, 2022). In a different vein, the study on the French healthcare organisations highlights that using performance measures may bring moral risks and injustice that require social actors to construct different arguments for different audiences (Moriniére and Georgescu, 2022). Sargiacomo and Walker's (2022) work on disaster governance argues that financial and non-financial measures were taken for various purposes, ranging from internal planning, coordination, decision-making and deviance analysis to external accountability. The public child protection agency study shows that "sequencing" is how accountants, caseworkers, consultants and managers pursue conflicting ideals of good performance (Schrøder et al., 2022). Finally, control mechanisms are also helpful in supporting the legitimacy of hybrid organisations. The case of purchaser-provider arrangements shows that different control mechanisms within a network should be scaled down to different subsets and establish icons without changing their meanings (Zawawi and Hoque, 2022).

\section{Conclusions and future research agendas}

This AAAJ special issue is an effort to create novel insights into different hybrid institutional contexts: for hybrid purpose institutional forms (benefit corporations); healthcare organisations; PPPs created for the delivery of school services; different forms of collaborative arrangements (alliances between public, private and non-profit organisations and purchaser-provider models); hybrid public entities for power administration, cultural events, social investments, social housing, ICT service provision, humanitarian activities connected to natural disasters and child protection. They have been conceptualised through hybridity as enacting three forms of value creation in hybrid organisations: mixing, compromising and legitimising. Mixing refers to the process of combining previously created or existing value categories with the aim of creating innovative variants, blends and layers of value (Convery and Kaufman, 2022; Rautiainen et al., 2022). Compromising concerns the governance of competing, contradicting and even conflictual values in hybrid arrangements through the reconciliation of different value propositions, owners and constituencies (Moriniére and Georgescu, 2022; Schrøder et al., 2022). Legitimising is a crucial concern for hybrid organisations as legitimacy demands from external audiences, society and media may impose constraints, limitations and important performance measurement and accountability problems. However, the same demands may be windows of opportunity for hybrid organisations as well as for blame avoidance and credit-seeking that can benefit from the multiplicity of legitimacy requirements (Baudot et al., 2022; Maine et al., 2022). In the AAAJ

Accounting in hybrid organisations

589 
AAAJ

35,3

590

special issue, these three mechanisms have been enhanced to understand the highly complicated characteristics of value creation in different settings of hybridity.

Concerning future directions on hybrids and hybridity, note that each of the articles selected in our special issue - and the related topics of investigation - may elucidate, per se, a precise line of inquiry to be a complement and to be extended by further research. In other words, all AAAJ special issue articles are linked to pivotal lines of inquiry and call for further research. For a more elaborate account, we introduce an additional categorisation of research streams where we acknowledge important potentials for the future research efforts.

\section{Hybridity and multiple values}

Interdisciplinary and critical accounting scholars have paid limited attention to the links around how different actors and their values affect goals in hybrid organisations and their role in developing performance measurement practices (Grossi et al., 2017, 2020). A notable exception is a study by Ferry and Slack (2022), who suggest the concept of dialogic tools to explain account for how accounting practices can facilitate compromise amongst different actors holding different values. Begkos and Antonopoulou's (2022) study on medical managers as "practitioners of hybridity" also highlights the value of performance metrics to reconcile different values, goals, identities and priorities. Nevertheless, there is still limited research explicitly focusing on the role of the different actors (accountants, controllers, auditors and professionals) in the design and implementation of performance and accountability practices in hybrid organisations (Skelcher and Smith, 2015; Berry et al., 2009; Campanale et al., 2021). Similarly, future research would likely benefit from studies inside hybrid organisations (Pache and Santos, 2013), seeking more in-depth insights into internal operational and accounting practices (e.g. Ahrens and Chapman, 2007; Jørgensen and Messner, 2010; Laguecir et al., 2021) and focusing more on the internal context where different actors operate to promote performance and accountability changes (Grossi et al., 2020).

\section{Hybridity in the governance of disasters and pandemics}

We are taking the example of Sargiacomo and Walker's (2022) study on disaster governance and hybrid organisations, which, in a COVID-19 pandemic time, can be connected to the issues raised by climate change and biological hazards. To date, there is still much to learn about the role of hybrid arrangements to prevent natural disasters (e.g. flooding in Rotterdam and Bad Ems, Germany), care for citizens threatened by major public health emergencies and repair communities in post-disaster scenarios. Let us think of the 1995 Kobe Earthquake, which, besides resulting in more than 6,000 victims, triggered estimated damage equal to $2.5 \%$ of Japan gross domestic product (GDP) or $102.5 \mathrm{Bln} / \$$. Let us also think of the 2011 Great East Japan Earthquake, connected to the ensuing tsunami and consequent nuclear accident to Fukushima Daiichi nuclear plants. Despite the time distance from the previous catastrophic events, we know precious little about the role of hybrid organisations as connected to these catastrophic events and the broader area of disasters (Sargiacomo, 2014), climate change and biological hazards.

\section{Hybridity and mega-projects}

In how many previously ignored cases did collaborative arrangements between public and private sector actors play a pivotal role in building cultural events? Consider Ferry and Slack (2022) who study the (counter) accounting for the hybrid organising of a significant cultural event, represented by the case of the Great Exhibition of the North. The topic of mega-cultural events is broad and may include, for example, the area of the Olympic Games, which influential commentators seem to address as one that has provoked, in the past half-century, 
vast losses of public money (Flyvbierg et al., 2021), at the same time using multiple PPPs and hybrid organisations for the engineering and building of stadiums and infrastructure. The topic of mega-cultural and sports events brings to the fore the idea of megaprojects, defined as "large-scale, complex ventures that typically cost US\$1 billion or more, take many years to develop and build, involve multiple public and private stakeholders [...] and impact millions of people" (Flyvbjerg, 2014, p. 6). Regrettably, they often go "over budget, over time, over and over again" (Flyvbjerg, 2011) as "the average practice" is "a disaster in this interesting and very costly area of management" (Flyvbjerg, 2014, p. 7). To date, the topic of "accounting for mega-projects, mega-events and hybrid organisations" was ignored and in need of research in a rarely investigated research avenue. Examples of novel research areas may include, but certainly are not limited to, the already built new Terminal 2 of London Heathrow (inaugurated in 2014), the execution of the Tokyo-Nagoya magnetically levitated high-speed rail system of transportation (MAGLEV) project and the still ongoing construction of the Italian-French collaborative transnational high-speed railway (TELT) megaproject. The same can be said with regards to the English-French Channel Tunnel, which at the time it was being built was the most expensive construction project ever conceived. Despite the costs skyrocketed beyond $€ 20 \mathrm{bn}$, the "Chunnel" transnational project, which actually consists of three tunnels inaugurated in 1994, has been completely overlooked by accounting research. The joint strike fighter (JSF) programme for the engineering and building of the F35 Lightning aircraft connects the national military defence of several countries and highlights another excellent example of hitherto-unexplored interrelations between accounting, megaprojects and hybrid organisations.

\section{Hybridity and sustainability}

Hybrid organisations are a clear example of organisations that experience the pressures of sustainability, and their complex hybrid nature has an impact on new corporate reporting practices (such as sustainability, integrated and sustainable development goals (SDGs) reporting) in a surprising way (Alexius and Grossi, 2018; Argento et al., 2019a; Guthrie and Martin-Sardesai, 2020; Manes Rossi et al., 2020). Sustainability strategies enable hybrid organisations to respond to the expectations of different stakeholders within and outside the organisations in obtaining different facets of performance (Maine et al., 2022). However, state ownership and control do not necessarily imply increased sustainability disclosure (Argento et al., 2019a). More research is needed on how different drivers connected to hybridity affect their sustainability and SDGs' disclosures. More research is needed on how hybrid organisations design, implement and use their sustainability and SDGs' reporting (Argento et al., 2019b).

Furthermore, consider the impact of public expenditure on infrastructure for the areas of education, health and social programmes to reduce inequalities in communities. This is pivotal for building more sustainable cities and regions of the future. According to Stafford and Stapleton (2022), regarding PPPs in education, Maine et al. (2022), regarding social housing, and Maran and Lowe (2022), regarding ICT in healthcare, there is still much to learn about the roles played by hybrid organisations and hybridity in such areas. For example, notably, the COVID-19 pandemic has raised a series of social concerns, including the assurance of the food security supply chain and the allocation of food to the poor and vulnerable population [1] (Sargiacomo et al., 2021). Nevertheless, this social concern connected to food insecurity and citizens' inequality (Andrew et al., 2020) existed well before the pandemic's arrival. Moreover, whilst, in most urban settings, hybrid organisations were already purposely set up - before the emergency - to try to solve this unresolved and growing global issue, accounting research to date has almost totally neglected this area of research. We are confident that all the above topics will deserve much more attention from the accounting community soon. 
AAAJ

35,3

592

Hybridity at different levels of governance

The characteristics, problems and implications of hybridity may vary at different levels of governance. Researchers have learnt to use organisations as an important frame for thinking about how and where social action occurs (Simon, 1991). This also remains an important starting point for a large part of the hybridity and hybrid governance research. However, this special issue has demonstrated the need to address the multi-faceted and complicated linkages between micro-, meso- and macro-levels of governance (Grossi et al., 2017; Vakkuri and Johanson, 2020). We need to understand how hybrid organisations, as the microconstructs of hybridity, are associated with meso-level fields of institutional activities and macro-level political orders in society (Besharov and Mitxinneck, 2021; Vakkuri et al., 2021). While it is evident that different disciplinary orientations introduce their own idiosyncrasies to how the level of analysis may be conceptualised, this issue has shown why and how the analysis of hybridity may benefit from the plethora of disciplinary perspectives. Insightful scrutiny of hybrid governance and organisations requires innovative inter-disciplinary frameworks for analysing how societal activities may transcend the boundaries between public, private and civil society and how the activities of hybrid organisations are embedded in a more comprehensive framework of hybrid governance.

\section{Note}

1. http://www.fao.org/2019-ncov/en/; https://www.feedingamerica.org/research/coronavirus-hungerresearch.

\section{References}

Ahrens, T. and Chapman, C.S. (2007), "Management accounting as practice", Accounting, Organisations and Society, Vol. 32 No. 1, pp. 1-27.

Alexius, S. and Cisneros Örnberg, J. (2015), "Mission(s) impossible? Configuring values in the governance of state owned enterprises", International Journal of Public Sector Management, Vol. 28 Nos 4/5, pp. 286-306.

Alexius, S. and Grossi, G. (2018), "Decoupling in the age of market-embedded morality: responsible gambling in a Hybrid Organization”, Journal of Management and Governance, Vol. 22 No. 2, pp. 285-313.

Almqvist, R., Grossi, G., van Helden, G.J. and Reichard, C. (2013), "Public sector governance and accountability", Critical Perspectives on Accounting, Vol. 24 Nos 7-8, pp. 479-487.

Andrew, J., Baker, M., Guthrie, J. and Martin-Sardesai, A. (2020), "Australia's COVID-19 public budgeting response: the straitjacket of neoliberalism", Journal of Public Budgeting, Accounting and Financial Management, Vol. 32 No. 5, pp. 759-770.

Argento, D., Grossi, G., Person, K. and Vingren, T. (2019a), "Explaining sustainability disclosures of hybrid organisations: the case of Swedish state-owned enterprises", Meditari Accountancy Research, Vol. 27 No. 4, pp. 505-533.

Argento, D., Culasso, F. and Truant, E. (2019b), "From sustainability to integrated reporting: the legitimising role of the CSR manager", Organization and Environment, Vol. 32 No. 4, pp. 484-507.

Badian, E. (1983), Publicans and Sinners: Private Enterprise in the Service of the Roman Republic, with a Critical Bibliography, Cornell University Press, Ithaca.

Battilana, J. and Lee, M. (2014), "Advancing research on hybrid organizing - insights from the study of social enterprises", The Academy of Management Annals, Vol. 8 No. 1, pp. 397-441.

Baudot, L., Dillard, J. and Pencle, N. (2022), "Hybrid organisations and an ethic of accountability: the role of accountability systems in constructing responsible hybridity", Accounting, Auditing and Accountability Journal, Vol. 35 No. 3, doi: 10.1108/AAAJ-11-2019-4287. 
Begkos, C. and Antonopoulou, K. (2022), "Hybridisation as practice: clinical engagement with performance metrics and accounting technologies in the English NHS", Accounting, Auditing and Accountability Journal, Vol. 35 No. 3, doi: 10.1108/AAAJ-12-2019-4333.

Berry, A.J., Coad, A.F., Harris, E.P., Otley, D.T. and Stringer, C. (2009), "Emerging themes in management control: a review of recent literature", The British Accounting Review, Vol. 41 No. 1, pp. 2-20.

Besharov, M.L. and Mitzinneck, B.C. (Eds) (2021), "Organizational hybridity. Perspectives, processes, promises", Research in the Sociology of Organisations, Edward Elgar, Bingley, Vol. 69.

Billis, D. and Rochester, R. (Eds) (2020), Handbook on Hybrid Organisations, Edward Elgar Publishing,

Accounting in hybrid organisations Cheltenham.

Bozeman, B. (2019), "Public values: citizens' perspective”, Public Management Review, Vol. 21 No. 6, pp. 817-838.

Bruton, G.D., Peng, M., Ajlstrom, D., Stan, C. and Xu, K. (2015), "State-owned enterprises around the world as hybrid organizations", Academy of Management Perspectives, Vol. 29 No. 1, pp. 92-114.

Bryson, J.M., Crosby, B.C. and Bloomberg, L. (2014), "Public value governance: moving beyond traditional public administration and the new public management", Public Administration Review, Vol. 74 No. 4, pp. 445-456.

Campanale, C., Cinquini, L. and Grossi, G. (2021), "Hybridity as instrumental value affecting management accounting in hybrid organisations", British Accounting Review, Vol. 35 No. 3, doi: 10.1016/j.bar.2021.100999.

Chenhall, R.H., Hall, M. and Smith, D. (2013), "Performance measurement, modes of evaluation and the development of compromising accounts", Accounting, Organisations and Society, Vol. 38 No. 4, pp. 268-287.

Coff, R.W. (1999), “When competitive advantage doesn't lead to performance: the resource-based view and stakeholder bargaining power", Organization Science, Vol. 10 No. 2, pp. 119-133.

Conrath-Hargreaves, A. and Wüstemann, S. (2019), "Multiple institutional logics and their impact on accounting in higher education: the case of a German foundation university", Accounting, Auditing and Accountability Journal, Vol. 32 No. 3, pp. 782-810.

Convery, A. and Kaufman, M. (2022), "Regulation as a force for hybrid organisation: evidence from the Bonneville Power Administration (1980-2012)", Accounting, Auditing and Accountability Journal, Vol. 35 No. 3, doi: 10.1108/AAAJ-12-2019-4327.

Costa, E. and Andreus, M. (2021), "Social impact and performance measurement systems in an Italian social enterprise: a participatory action research project", Journal of Public Budgeting, Accounting and Financial Management, Vol. 33 No. 3, pp. 289-313.

De Waele, L., Polzer, T., van Witteloostuijn, A. and Berghman, L. (2021), “'A little bit of everything?' Conceptualising performance measurement in hybrid public sector organisations through a literature review", Journal of Public Budgeting, Accounting and Financial Management, Vol. 33 No. 3, pp. 343-363.

Emerson, J. (2003), "The blended value proposition: integrating social and financial returns", California Management Review, Vol. 45 No. 4, pp. 35-51.

Ferry, L. and Slack, R. (2022), “(Counter) accounting for hybrid organising: a case of the great exhibition of the north, accounting", Auditing and Accountability Journal, Vol. 35 No. 3, doi: 10.1108/AAAJ12-2019-4303.

Flyvbjerg, B. (2011), "Over budget, over time, over and over again: managing major projects", in Morris, P.W.G., Pinto, J.K. and Söderlund, J. (Eds), The Oxford Handbook of Project Management, Oxford University Press, Oxford, England, pp. 321-344.

Flyvbjerg, B. (2014), "What you should know about megaprojects and why: an overview", Project Management Journal, April-May, pp. 6-19.

Flyvbjerg, B., Budzier, A. and Lunn, D. (2021), "Regression to the tail: why the olympics blow up", Economy and Space, Vol. 53 No. 2, pp. 233-260. 
AAAJ 35,3

Giosi, A. and Caiffa, M. (2020), "Political connections, media impact and state-owned enterprises: an empirical analysis on corporate financial performance", Journal of Public Budgeting, Accounting and Financial Management, Vol. 32 No. 3, pp. 261-288.

Grossi, G., Reichard, C., Thomasson, A. and Vakkuri, J. (2017), "Theme: performance measurement of hybrid organisations - emerging issues and future research perspectives", Public Money and Management, Vol. 37 No. 6, pp. 379-386.

Grossi, G., Kallio, K.M., Sargiacomo, M. and Skoog, M. (2020), “Accounting, performance management systems and accountability changes in knowledge-intensive public organisations: a literature review and research agenda", Accounting, Auditing and Accountability Journal, Vol. 33 No. 1, pp. 256-280.

Guthrie, J. (1993), "Australian public business enterprises: analysis of changing accounting, auditing, and accountability regimes", Financial Accountability and Management, Vol. 9 No. 2, pp. 101-114.

Guthrie, J. and Martin-Sardesai, A. (2020), "Contemporary challenges in public sector reporting”, in Manes Rossi, F. and Orelli, R. (Eds), Reflections on New Trends in Public Sector Reporting: Integrated Reporting and Beyond, Palgrave Macmillan, London, pp. 1-14.

Haigh, N., Walker, J., Bacq, S. and Kickul, J. (2015), "Hybrid organisations”, California Management Review, Vol. 57 No. 3, pp. 5-12.

Hood, C. (2000), "Paradoxes of public-sector managerialism, old public management and public service bargains”, International Public Management Journal, Vol. 3 No. 1, pp. 1-22.

Hopwood, A. (1996), "Looking across rather than up and down: on the need to explore the lateral processing of information", Accounting, Organisations and Society, Vol. 21 No. 6, pp. 589-590.

Hyndman, N. and McConville, D. (2018), "Trust and accountability in UK charities: exploring the virtuous circle", The British Accounting Review, Vol. 50 No. 2, pp. 227-237.

Jacobides, M.G., Knudsen, T. and Augier, M. (2006), "Benefiting from innovation: value creation, value appropriation and the role of industry architectures", Research Policy, Vol. 35 No. 8, pp. $1200-1221$.

Jeavons, T.H. (1992), "When the management is the message: relating values to management practice in non-profit organisations", Non-profit Management and Leadership, Vol. 2 No. 4, pp. 403-417.

Johanson, J.E. and Vakkuri, J. (2017), Governing Hybrid Organisations. Exploring Diversity of Institutional Life, Routledge, Abingdon, New York, NY.

Jørgensen, B. and Messner, M. (2010), "Accounting, and strategising: a case study from new product development”, Accounting, Organisations and Society, Vol. 35 No. 2, pp. 184-204.

Karré, P. (2020), "Value creation by two types of hybrid organisations: opportunities and risks", in Vakkuri, J. and Johanson, J.E. (Eds), Hybrid Governance, Organisation and Society. Value Creation Perspectives, Routledge, Abingdon, New York, NY, pp. 202-217.

Kastberg Weichselberger, G. and Lagström, C. (2019), "Processes of hybridisation and dehybridisation: organising and the task at hand", Accounting, Auditing and Accountability Journal, Vol. 32 No. 3, pp. 710-726.

Kastberg Weichselberger, G. and Lagström, C. (2022), "Accounting in and for hybrids. Observations of the power of disentanglements", Accounting, Auditing and Accountability Journal, Vol. 35 No. 3 , doi: 10.1108/AAAJ-12-2019-4318.

Kiser, L. and Ostrom, E. (1982), The Three Worlds of Political Action Strategies of Political Inquiry, Sage, Beverly Hills.

Kreps, T. and Monin, B. (2011), "Doing well by doing good? Ambivalent moral framing in organisations", Research in Organizational Behavior, Vol. 31 No. 2, pp. 99-123.

Kurunmaki, L. (2004), "A hybrid profession, the acquisition of management accounting expertise by medical professionals”, Accounting, Organization and Society, Vol. 29 Nos 3-4, pp. 327-347. 
Kurunmaki, L. and Miller, P. (2006), "Modernising government: the calculating self hybridisation and performance measurement", Financial Accountability and Management, Vol. 22 No. 1, pp. 87-106.

Laguecir, A., Kern, A. and Kharoubi, C. (2021), "Management accounting systems in institutional complexity: hysteresis and boundaries of practices in social housing", Management Accounting Research, Vol. 35 No. 3, doi: 10.1016/j.mar.2020.100715.

Lepak, D.P., Smith, K.G. and Taylor, M. (2007), "Value creation and value capture: a multilevel perspective”, Academy of Management Review, Vol. 32 No. 1, pp. 180-194.

Mahoney, J., Mcgahan, A. and Pitelis, C. (2009), "The interdependence of private and public interests", Organization Science, Vol. 20 No. 6, pp. 1034-1052.

Maine, J., Samuelsson, E.F. and Uman, T. (2022), "Ambidextrous sustainability, organisational structure and performance in hybrid organisations", Accounting, Auditing and Accountability Journal. doi: 10.1108/AAAJ-12-2019-4338.

Manes Rossi, F., Niccoló, G. and Argento, D. (2020), "Non-financial reporting formats in public sector organizations: a structured literature review", Journal of Public Budgeting, Accounting and Financial Management, Vol. 32 No. 4, pp. 639-666.

Maran, L. and Lowe, A. (2022), "Competing logics in a hybrid organization: ICT service provision in the Italian healthcare", Accounting, Auditing and Accountability Journal, Vol. 35 No. 3, doi: 10. 1108/AAAJ-12-2019-4334.

Matten, M. and Moon, J. (2008), “Implicit' and 'explicit' CSR: a conceptual framework for a comparative understanding of corporate social responsibility", Academy of Management Review, Vol. 33 No. 2, pp. 404-424.

Mazzucato, M. (2018), The Value of Everything. Making and Taking in the Global Economy, Allen Lane; Penguin Books, Milton Keynes.

Modell, S. (2019), "Constructing institutional performance: a multi-level framing perspective on performance measurement and management", Accounting and Business Research, Vol. 49 No. 4, pp. $428-453$.

Modell, C. (2021), "New developments in institutional research on performance measurement and management in the public sector", Journal of Public Budgeting, Accounting and Financial Management. doi: 10.1108/JPBAFM-04-2021-0070.

Mongelli, L., Rullani, F., Ramus, T. and Rimac, T. (2019), "The bright side of hybridity: exploring how social enterprises manage and leverage their hybrid nature", Journal of Business Ethics, Vol. 159 No. 4, pp. 301-305.

Moore, M.H. (1995), Creating Public Value: Strategic Management in Government, Harvard University Press, Harvard.

Moriniére, A. and Georgescu, I. (2022), "Hybridity and the use of performance measurement: facilitating compromises or creating moral struggles? Insights from healthcare organisations", Accounting, Auditing and Accountability Journal. doi: 10.1108/AAAJ-12-2019-4309.

Moynihan, D.P. (2005), "Goal-based learning and the future of performance management", Public Administration Review, Vol. 65 No. 2, pp. 203-216.

Nicholls, A. (2009), “We do good things, don't we?': 'Blended value accounting' in social entrepreneurship", Accounting, Organisations and Society, Vol. 34 Nos 6-7, pp. 755-769.

Noordegraaf, M. (2007), "From 'pure' to 'hybrid' professionalism: present-day professionalism in ambiguous public domains", Administration and Society, Vol. 39 No. 6, pp. 761-785.

Okhmatovskiy, I., Grosman, A. and Sun, P. (2021), "Hybrid governance of state-owned enterprises", in Wright, M., Wood, G., Cuervo-Cazurra, A., Sun, P., Okhmatovskiy, I. and Grosman, A. (Eds), Oxford Handbook of State Capitalism and the Firm, Oxford University Press, Oxford.

Ostrom, E. (2005), Understanding Institutional Diversity, Princeton University Press, Princeton. 
AAAJ 35,3

Pache, A. and Santos, F. (2013), "Inside the hybrid organisation: selective coupling as a response to competing institutional logics", Academy of Management Journal, Vol. 56 No. 4, pp. 972-1001.

Pfeffer, J. and Sutton, R.I. (1999), The Knowing-Doing Gap. How Smart Companies Turn Knowledge into Action, Harvard Business School Press, Boston.

Plé, L. and Gáceres, R.C. (2010), "Not always co-creation: introducing interactional co-destruction of value in service-dominant logic", Journal of Services Marketing, Vol. 24 No. 6, pp. 430-437.

Polzer, T., Meyer, R.E., Höllerer, M.A. and Seiwald, J. (2016), "Institutional hybridity in public sector reform: replacement, blending, or layering of administrative paradigms", Research in the Sociology of Organisations, Vol. 48B, pp. 69-99.

Porter, M.E. and Kramer, M.R. (2011), "The big idea creating shared value”, Harvard Business Review, Vol. 89 Nos 1-2, pp. 2-17.

Quélin, B.V., Kivleniece, I. and Lazzarini, S. (2017), "Public-private collaboration, hybridity and social value: towards new theoretical perspectives", Journal of Management Studies, Vol. 54 No. 6, pp. 763-792.

Rajala, T. and Kokko, P. (2022), "Biased by design - the case of horizontal accountability in a hybrid organisation", Accounting, Auditing and Accountability Journal, Vol. 35 No. 3, doi: 10.1108/ AAAJ-11-2019-427.

Ramirez, R. (1999), "Value co-production: intellectual origins and implications for practice and research", Strategic Management Journal, Vol. 20 No. 1, pp. 49-65.

Rautiainen, A., Mättö, T., Sippola, K. and Pellinen, J.O. (2022), “Accounting, microfoundations, hybridisation and longitudinal conflicts in a Finnish healthcare organisation", Accounting, Auditing and Accountability Journal, Vol. 35 No. 3, doi: 10.1108/AAAJ-12-2019-4313.

Sargiacomo, M. (2014), “Accounting for natural disasters and humanitarian interventions”, Critical Perspectives on Accounting, Vol. 25 No. 7, pp. 576-578.

Sargiacomo, M. and Walker, S. (2022), "Disaster governance and hybrid organisations: accounting, performance challenges and evacuee housing", Accounting, Auditing and Accountability Journal, Vol. 35 No. 3, doi: 10.1108/AAAJ-12-2019-4323.

Sargiacomo, M., Corazza, L., D’Andreamatteo, A., Dumay, J. and Guthrie, J. (2021), "COVID-19 and the governmentality of emergency food in the City of Turin", Accounting, Auditing and Accountability Journal, Vol. 34 No. 6, pp. 1457-1470.

Schrøder, I., Cedeberg, E. and Hauge, A.M. (2022), "What is a good work in a hybrid organisation? On the efforts of sequencing registers of valuation", Accounting, Auditing and Accountability Journal, Vol. 35 No. 3, doi: 10.1108/AAAJ-12-2019-4328.

Simon, H.A. (1991), “Organisations and markets”, Journal of Economic Perspectives, Vol. 5 No. 2, pp. 25-44.

Skelcher, C. and Smith, S. (2015), "Theorising hybridity: institutional logics, complex organisations, and actor identities: the case of non-profits", Public Administration, Vol. 93 No. 2, pp. 433-448.

Stafford, A. and Stapleton, P. (2022), "The impact of hybridity on PPP governance and related accountability mechanisms: the case of U.K. education PPPs", Accounting, Auditing and Accountability Journal, Vol. 35 No. 3, doi: 10.1108/AAAJ-12-2019-4324.

Suddaby, R., Bitektine, A. and Haack, P. (2017), "Legitimacy", Academy of Management Annals, Vol. 11 No. 1, pp. 451-478.

Teece, D.J. (1986), "Profiting from technological innovation: implications for integration, collaboration, licensing and public policy", Research Policy, Vol. 15 No. 6, pp. 285-305.

Thornton, P.H., Ocasio, W. and Lounsbury, M. (2012), The Institutional Logics Perspective: A New Approach to Culture, Structure, and Process, Oxford University Press, New York, NY.

Vakkuri, J. (2010), "Struggling with ambiguity - public managers as users of NPM-oriented management instruments", Public Administration, Vol. 88 No. 4, pp. 999-1024. 
Vakkuri, J. and Johanson, J.-E. (2020), "Value creation among hybrids", in Vakkuri, J. and Johanson, J.E. (Eds), Hybrid Governance, Organisations and Society. Value Creation Perspectives, Routledge, Abingdon, New York, NY, pp. 3-25.

Vakkuri, J., Johanson, J.-E., Feng, N.C. and Giordano, F. (2021), "Governance and accountability in hybrid organisations - past, present and future", Journal of Public Budgeting, Accounting and Financial Management, Vol. 33 No. 3, pp. 245-260.

Vatin, F. (2013), "Valuation as evaluating and valorising", Valuation Studies, Vol. 1 No. 1, pp. 31-50.

Zawawi, N.H.M. and Hoque, Z. (2022), "Network control and balanced scorecard as inscriptions in purchaser-provider arrangements: insights from a hybrid government agency", Accounting, Auditing and Accountability Journal, Vol. 35 No. 3, doi: 10.1108/AAAJ-11-2019-4242.

\section{Further reading}

Grossi, G. and Thomasson, A. (2015), "Bridging the accountability gap in hybrid organisations. The case of Malmö Copenhagen Port", International Review of Administrative Sciences, Vol. 81 No. 3, pp. 604-620.

\section{Corresponding author}

Giuseppe Grossi can be contacted at: giuseppe.grossi@hkr.se

For instructions on how to order reprints of this article, please visit our website:

www.emeraldgrouppublishing.com/licensing/reprints.htm

Or contact us for further details: permissions@emeraldinsight.com 